\title{
The analysis of health behaviors and illness acceptance in patients with diabetes
}

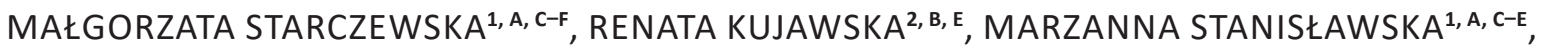 \\ ANITA RYBICKA ${ }^{1, B, D, F}$, ELŻBIETA GROCHANS ${ }^{1, D, G}$
}

${ }^{1}$ Department of Nursing, Pomeranian Medical University, Szczecin, Poland

${ }^{2}$ Students' Scientific Circle at the Department of Nursing, Pomeranian Medical University, Szczecin, Poland

A - Study Design, B - Data Collection, C - Statistical Analysis, D - Data Interpretation, E - Manuscript Preparation, F - Literature Search, G - Funds Collection

Summary Background. Presently, diabetes is one of the major problems of healthcare, both in medical and socio-economic terms, in most countries worldwide. A key role in the proper functioning of diabetic patients is played by health behaviors, which result in specific health effects.

Objectives. The analysis of health behaviors and illness acceptance in patients with diabetes.

Material and methods. The study was conducted at the National Health Care Centre "KMW Centrum Zdrowia" in Stargard. The study included 215 people aged 30-87 suffering from diabetes. The study was carried out by means of a diagnostic survey method, and the research tool used was a questionnaire. It consisted of three parts, the first of which was the authors' questionnaire, the second was the Health Behavior Inventory (HBI), and the third was the Acceptance of Illness Scale (AIS).

Results. An analysis of the results has shown that the majority of the study sample (59.1\%) gained high scores for an increase on health behaviors according to the $\mathrm{HBI}$ - approximately $7-10$ sten scores. The average level of an overall increase in health behaviors exhibited by the participants (HBI) amounted to $91.0 \pm 14.82$ points. The respondents demonstrated similar levels of average results regarding all categories of health behaviors according to the HBI. Data analysis related to illness acceptance has indicated that the average level of illness acceptance of the study subjects amounted to $31.80 \pm 7.91$ points.

Conclusions. Patients with diabetes showed high levels of health behaviors and illness acceptance, and the results depended upon the subjects' education, duration of the illness and health education. Females and patients suffering from diabetes for a long period of time require psychological support to resolve disease-related problems, cope with difficulties and develop positive attitudes towards the disease.

Key words: diabetes mellitus, health, Acceptance of IIIness Scale (AIS).

Starczewska M, Kujawska R, Stanisławska M, Rybicka Anita, Grochans E. The analysis of health behaviors and illness acceptance in patients with diabetes. Fam Med Prim Care Rev 2018; 20(4): 352-355, doi: https://doi.org/10.5114/fmpcr.2018.79347.

\section{Background}

Presently, diabetes is one of the major healthcare problems, both in medical and social-economic terms, in most of the countries worldwide [1].

According to the report of the World Health Organization in 2014, 422 million people suffered from diabetes in the world, of which 64 million diabetics lived in Europe. An almost two-fold increase in diabetes was reported in relation to 1980 . In 2012, this disease was the cause of 1.5 million deaths in the world, and an additional 2.2 million deaths occurred due to elevated blood glucose levels leading to cardiovascular diseases and disorders in other systems [2]. In Poland, about 3 million Poles are struggling with this disease, of whom about 1 million do not know that they are suffering from the disease [3].

A key role in the proper functioning of diabetic patients is played by health behaviors, which result in specific health effects. Behaviors associated with the type of food consumed, compliance with health recommendations, finding information on health and the disease, developing positive sleep and motor activity habits, as well as avoiding strong emotions and stress may have a significant influence on the course of the disease and positively affect the body, which may be a criterion to regain optimal health status $[1,4]$. Taking specific health actions by the patient is the effect of an attitude towards health, which is shaped during childhood and adolescence, and is then established during adulthood. The basic role in the modification of behaviors is played by health education, which is the basic component of therapeutic treatment. The essence of educational activities is the acquisition by the patient of both information and skills facilitating the making of informed health decisions based on scientifically proven knowledge $[5,6]$. Research shows that the choice of health-related behaviors is also significantly affected by the internal resources of the patient, including optimism, positive psychological attitude, self-efficacy and internal location of health control [7].

Chronic diseases, which includes diabetes, change one's perception of the world and change the lives of the majority of patients, who re-evaluate their life priorities. Acceptance of the disease does not come easy, and there are people who acknowledge the diagnosis and the state of the disease, while others cannot reconcile with the diagnosis. The attitude of the patient towards the disease is expressed in the specific behavior of the ill person, as well as in his emotional experiences. The condition and related limitations significantly worsen the patient's somatic well-being and increase his/her irritability and psychological tension, which may be the reason for conflicts in the family and lower self-esteem, and thus will not support the mobilization of the patient's strength in the fight against the disease. Finding 
a patient in a new situation can be difficult, and the acceptance of the disease requires him/her to understand the nature of the illness and adhere to the recommendations and self-discipline. A patient that has accepted the disease is more willing to participate in the treatment process $[8,9]$.

Research in the field of health behaviors exhibited by diabetic patients and the level of their illness acceptance may allow for assessment of the effectiveness of health education, as well as for planning actions that increase its effectiveness.

\section{Objectives}

The aim of this study was analysis of health behaviors and illness acceptance in diabetic patients with regard to sociometric and medical data. Our assumption was to check whether the duration of the disease, level of education and frequency of taking part in training on diabetes are related to health behaviors and the level of illness acceptance. We also assumed that the gender of the respondents has a significant impact on their health behaviors and the level of illness acceptance.

\section{Material and methods}

\section{Setting}

The study was conducted from July to the end of September 2018 at the National Health Care Centre "KMW Centrum Zdrowia" in Stargard.

\section{Participants}

The study sample was comprised of patients of the diabetic outpatient clinic, namely 215 subjects aged $30-87$, including 124 females and 91 males. The selection method involved random sampling, namely dependent sampling. The study was carried out in every fifth patient diagnosed with diabetes who showed up at the outpatient clinic, after expressing informed consent to undergo the survey.

\section{Measurement}

The diagnostic survey method was used to carry out the study - the technique applied was an auditorium questionnaire, and the research tool was a questionnaire. It consisted of three parts, the first of which was the authors' questionnaire, the second was the Health Behavior Inventory ( $\mathrm{HBI}$ ), and the third was the Acceptance of Illness Scale (AIS).

The authors' questions concerned patients' age, gender, education, marital status, body weight and height, duration and type of diabetes and participation in training on diabetes.

The HBI comprises 24 questions divided into four groups regarding: positive mental attitude, preventive behaviors, proper eating habits and health practices. The respondents mark the frequency of particular health practices on the scale, where 1 stands for - almost never, 2 - seldom, 3 -from time to time, 4 - often, 5 - almost always. The possible scores range from 24 to 240 - the higher the score, the higher the level health behaviors. The results are converted into sten scores. Sten scores of 1-4 are regarded as low, 5-6 as average, and 7-10 as high [10].

The Acceptance of Illness Scale (AIS) contains eight questions referring to negative consequences of ill health. These consequences relate to accepting the limitations of the illness, lack of self-reliance, dependence upon others, lowered self-esteem. For each question, the respondents marked their levels of illness acceptance on a five-point Likert scale, with 1 denoting poor adaptation to the disease, and 5 - acceptance of the disease. The sum of the points reflects general acceptance of illness; 40 points means full acceptance of illness [10].
The analysis of health behaviors and illness acceptance was conducted with respect to the following variables: gender, education, duration of the illness and frequency of participation in diabetes awareness training.

\section{Statistical methods}

The results were described in terms of means and standard deviations (for the entire study sample). Owing to the lack of normal distribution, the analysis of the $\mathrm{HBI}$ results with regard to gender required the use of the nonparametric Mann-Whitney $U$ test. In order to define the intensity of correlation between two variables, Pearson's correlation coefficient $r$ was used. Moreover, the non-parametric Spearman rank correlation was applied, which enabled analysis of the relationship between variables measured in the order scale. In the study, the level of significance was set at 0.05 . The analysis was carried out with SPSS for Windows 17.0.

The research followed the Declaration of Helsinki. It did not require the consent of the Bioethics Commission.

\section{Results}

\section{Participants and descriptive data}

The study involved 215 people suffering from diabetes, including 91\% with type 2 diabetes, $8 \%$ with type 1 diabetes, and only $1 \%$ had type 3 diabetes. The respondents comprised 124 females (57.7\%) and 91 males (42.3\%). The duration of the illness spanned between 1 and 50 years, with a mean duration of $10 \pm 9$ years. The majority of the patients had been married $-62.8 \%$; there were also $31.6 \%$ listed as single, and $5.6 \%$ of the respondents had been in non-marital relationships. The largest group consisted of people with secondary education, and the smallest one - of those with tertiary education.

The minimum body weight of the respondents was $52 \mathrm{~kg}$, the maximum weight was $142 \mathrm{~kg}$, and the average weight was $86 \mathrm{~kg}$. The respondents' height ranged from 150 to $194 \mathrm{~cm}$, and the average height was $167 \mathrm{~cm}$. The minimum BMI was 15.41, the maximum BMI was 49.82, and the average BMI was 31.04.

\section{Main results}

As the analysis of results has shown, the majority of the subjects $(59.1 \%)$ scored high for an increase on health behaviors according to the $\mathrm{HBI}$ - between 7-10 sten scores. Average results (between 5 and 6 sten scores) were achieved by $26.5 \%$ of those studied, while low results (between 1 and 4 sten scores) were attained by $14.4 \%$ of the respondents.

The lowest value of the overall index of increase on health behaviors (HBI) in the subjects amounted to 35 points, while the highest -119 points, and the average level of the overall index of increase on health behaviors (HBI) was $91.0 \pm 14.82$.

The respondents reached similar levels of average results with respect to all the categories of health behaviors according to the $\mathrm{HBI}$. The smallest increase was demonstrated regarding positive mental attitudes, whereas the largest increase concerned proper eating habits and preventive behaviors.

The analysis of data related to illness acceptance demonstrated that the minimum level of illness acceptance by those studied according to the AIS was 8 points, and the maximum level -40 points, whilst the average level amounted to $31.80 \pm 7.91$.

The analysis of average health behaviors according to the $\mathrm{HBI}$, as well as analysis of the AIS data with respect to gender, did not show any statistically significant differences $(p>0.05)$ (Table 1).

In turn, the analysis of particular categories of health behaviors demonstrated that males showed a significantly higher level of increase in positive mental attitudes $(p<0.05)$, as well as a significant result in the HBI sten scale (Table 1 ). 


\begin{tabular}{|c|c|c|c|c|}
\hline \multirow{3}{*}{ Scales } & \multirow[t]{2}{*}{ Category } & \multicolumn{3}{|c|}{ Descriptive statistics } \\
\hline & & Me & $z$ & $p$ \\
\hline & \multicolumn{4}{|l|}{ Gender } \\
\hline \multirow{2}{*}{ Proper eating habits } & females & 24 & \multirow[t]{2}{*}{1.11} & \multirow[t]{2}{*}{$>0.05$} \\
\hline & males & 23 & & \\
\hline \multirow[t]{2}{*}{ Preventive behaviors } & females & 24 & \multirow[t]{2}{*}{0.51} & \multirow[t]{2}{*}{$>0.05$} \\
\hline & males & 23 & & \\
\hline \multirow[t]{2}{*}{ Positive mental attitude } & females & 20 & \multirow[t]{2}{*}{2.82} & \multirow[t]{2}{*}{$\leq 0.005$} \\
\hline & males & 23 & & \\
\hline \multirow[t]{2}{*}{ Health practices } & females & 22 & \multirow[t]{2}{*}{0.76} & \multirow[t]{2}{*}{$>0.05$} \\
\hline & males & 22 & & \\
\hline \multirow[t]{2}{*}{$\mathrm{HBI}$} & females & 91 & \multirow[t]{2}{*}{0.67} & \multirow[t]{2}{*}{$>0.05$} \\
\hline & males & 91 & & \\
\hline \multirow[t]{2}{*}{$\mathrm{HBI}$ - sten scores } & females & 6 & \multirow[t]{2}{*}{2.92} & \multirow[t]{2}{*}{$\leq 0.003$} \\
\hline & males & 7 & & \\
\hline \multirow[t]{2}{*}{ AIS } & females & 32 & \multirow[t]{2}{*}{0.9} & \multirow[t]{2}{*}{$>0.05$} \\
\hline & males & 31 & & \\
\hline
\end{tabular}

Me - median, Z - U Mann-Whitney test, $p$ - level of significance.

The analysis of correlations has shown that the longer the disease lasted, the lower the degree of its acceptance was seen in the subjects $(p<0.05)$ (Table 2$)$. It has also been proven that the higher the level of education of the respondents, the higher the level of health behaviors observed in them; they presented a higher overall index of increase of health behaviors according to the $\mathrm{HBI}$ and gained higher sten scores. Furthermore, the higher the education level, the higher the degree of illness acceptance observed according to the AIS (Table 2).

The analysis of correlations indicates that the less frequently the respondents participated in diabetes awareness training, the higher their levels of health behaviors and the higher the degree of illness acceptance (Table 2).

\begin{tabular}{|c|c|c|c|c|c|c|}
\hline \multirow[t]{2}{*}{ Variables } & \multicolumn{2}{|c|}{$\begin{array}{l}\text { Duration of } \\
\text { diabetes }\end{array}$} & \multicolumn{2}{|c|}{$\begin{array}{l}\text { Level of educa- } \\
\text { tion }\end{array}$} & \multicolumn{2}{|c|}{$\begin{array}{l}\text { Frequency of } \\
\text { participation in } \\
\text { training }\end{array}$} \\
\hline & $r$ & $p$ & $R$ & $p$ & $R$ & $p$ \\
\hline $\begin{array}{l}\text { Proper } \\
\text { eating } \\
\text { habits }\end{array}$ & 0.04 & $>0.05$ & 0.29 & $<0.001$ & -0.37 & $<0.001$ \\
\hline $\begin{array}{l}\text { Preven- } \\
\text { tive } \\
\text { behaviors }\end{array}$ & 0.07 & $>0.05$ & 0.32 & $<0.001$ & -0.26 & $<0.001$ \\
\hline $\begin{array}{l}\text { Positive } \\
\text { mental } \\
\text { attitude }\end{array}$ & -0.02 & $>0.05$ & 0.29 & $<0.001$ & -0.30 & $<0.001$ \\
\hline $\begin{array}{l}\text { Health } \\
\text { practices }\end{array}$ & 0.12 & $>0.05$ & 0.21 & 0.002 & -0.24 & $<0.001$ \\
\hline $\mathrm{HBI}$ & 0.07 & $>0.05$ & 0.33 & $<0.001$ & -0.36 & $<0.001$ \\
\hline $\begin{array}{l}\mathrm{HBI} \text { - sten } \\
\text { scores }\end{array}$ & 0.08 & $>0.05$ & 0.33 & $<0.001$ & -0.34 & $<0.001$ \\
\hline AIS & -0.30 & $<0,001$ & 0.29 & $<0.001$ & -0.25 & $<0.001$ \\
\hline
\end{tabular}

$r$-Pearson correlation coefficient $r ; R$-Spearman rank correlation coefficient; $p$ - level of significance.

\section{Discussion}

\section{Key results}

Regarding health behaviors of patients with diabetes according to sten norms, the majority of the subjects scored highly - between 7-10 sten scores (59.1\%) - which is confirmed in study results by Kropornicka et al. [10]. In the study conducted by Kurpas et al. among chronically ill patients, females received average results according to sten norms, around 6 sten scores, whereas males scored highly, around 7 sten scores [11], which our study results verify.

In our own study, the obtained results for particular categories of health behaviors demonstrate an approximate average level. Similar results were achieved in the study cited above by Kurpas et al. [11]. However, Smoleń et al. attained a high index of health behaviors with respect to the $\mathrm{HBI}$ in a group of senior respondents [12].

In the study by Kurowska and Lach, average illness acceptance ( 25.16 points) was shown in patients with type 2 diabetes [8]. According to our study, there was no gender-dependent difference regarding the degree of illness acceptance. The study carried out by Moczydłowska et al. confirmed the obtained result [13].

In our study, males demonstrated a higher level of positive mental attitude than females $(p<0.005)$. The study results by Kurowska and Szomszor are similar as well [1].

The respondents declaring a higher level of education presented a higher level of health behaviors according to the HBI, as well as a higher level of illness acceptance according to the AIS. In the study conducted by Grochans et al. and Ślusarska et al., a similar correlation between education and the degree of increase of health behaviors was noted [14, 15]. Kurowska and Sulkowska, in their study, do not show a correlation between education and the degree of increase of health behaviors according to the $\mathrm{HBI}[16]$. The study by Szafraniec et al. indicates that the respondents' level of education did affect the level of illness acceptance. Those surveyed with tertiary education obtained the highest mean value. The lowest index of illness tolerance was observed in those with elementary education [17], which was confirmed by our own study results. In turn, Olszak et al. proved that no statistically significant difference was noted ( $p$ $>0.05$ ) between education and the AIS [18].

The analysis of correlations in our study has shown that the longer the illness lasted, the lower the level of illness acceptance according to the AIS. Olszak et al. have demonstrated statistically significant differences $(p<0.05)$ between the group of people suffering for $1-5$ years and those who have been ill for over 21 years [18]. In the study by Kurowska and Lach, the highest levels of illness acceptance were shown by patients with diabetes who have been ill for under a year, and the lowest, on the other hand, by those who have suffered for over 10 years [8].

The analysis of correlations in our study indicates that the less frequently the study subjects participated in diabetes awareness training sessions, the higher their levels of health behaviors and sten norms according to the $\mathrm{HBl}$; moreover, they also proved to have higher levels of illness acceptance according to the AIS.

According to the study carried out by Araszkiewicz et al., the patients who attended educational meetings presented a remarkably higher level of knowledge about the disease than the non-participating patients [19].

\section{Interpretation}

It is worth emphasizing that actions taken as part of health education in order to shape patients' health behaviors are nowadays regarded not only as support, but as a fundamental element of diabetes treatment. The strengthening of patients' 
motivation and improving their self-control and self-care skills through providing them with theoretical and practical knowledge will undoubtedly be a significant contribution to their awareness, will help them adapt to a new life situation and will let them accept the disease [20].

\section{Limitations of the study}

Our study has some limitations. This analysis only includes a small number of potentially relevant variables. We did not take into account other variables (for example marital status, income, support from the family, concomitant diseases) that can be essential for health behaviors and illness acceptance. Another limitation is the fact that the study sample was not a homogeneous group, since patients with different types of diabetes were analyzed. The scientific value of the study would probably be higher if it had included a control group consisting of patients with type 1 diabetes or another chronic disease.

\section{Conclusions}

Health behaviors and illness acceptance in patients with diabetes have been proven to be at high levels and dependent upon education, illness duration and health awareness education.

Females and patients suffering from diabetes for a long period of time require psychological support to resolve disease-related problems, cope with difficulties and develop positive attitudes towards the disease.

Source of funding: This work was funded by the authors' own resources.

Conflicts of interest: The authors declare no conflicts of interest.

\section{References}

1. Kurowska K, Szomszor M. Wpływ zachowań zdrowotnych na jakość życia u osób z rozpoznaniem cukrzycy typu 2. Diabetol Prakt 2011; 12(4): 142-150 (in Polish).

2. Global Report on Diabetes. World Health Organization 2016 [cited 21.07.2018]. Available from URL: http://www.who.int/diabetes/ global-report/en/.

3. Projekt „Cukrzyca 2025. Strategia Prewencji i Leczenia Cukrzycy w Polsce”. Instytut Pacjenta i Edukacji Zdrowotnej oraz Koalicji na Rzecz Walki z Cukrzycą, we współpracy z organizacjami pacjentów diabetologicznych 2016 [cited 21.07.2018]. Available from URL: http:// cukrzyca.ippez.pl/cukrzyca2/wp-content/uploads/2017/08/Cukrzyca-2025.pdf (in Polish).

4. Kulik A, Grądziel J, Smotrycka A. Zachowania zdrowotne studentek - charakterystyka i znaczenie zmiennych socjodemograficznch. Pol Hig Epidemiol 2017; 98(4): 371-380 (in Polish).

5. Kurowska K, Toś M. Poczucie własnej skuteczności a zachowania zdrowotne w grupie osób z rozpoznaniem cukrzycy typu 2. Pol Prz Nauk Zdr 2017; 1(50): 31-37, doi: https://doi.org/10.20883/ppnoz.2017.4 (in Polish).

6. Michalski P. Kosobucka A, Nowik M, et al. Edukacja zdrowotna pacjentów z chorobami układu sercowo-naczyniowego. Folia Cardiol 2016; 11(6): 519-524, doi: 10.5603/FC.a2016.0104 (in Polish).

7. Zalewska-Puchała J, Majda A, Korzonek R. Zachowania zdrowotne i poczucie własnej skuteczności studentów w utrzymaniu zdrowia. Probl Piel 2013; 14(10): 395-408 (in Polish).

8. Kurowska K, Lach B. Akceptacja choroby i sposoby radzenia sobie ze stresem u chorych na cukrzycę typu 2. Diabetol Prakt 2011; 12(3): 113-119 (in Polish).

9. Jurczyński Z. Narzędzia pomiaru w promocji i psychologii zdrowia. Warszawa: Pracownia Testów Psychologicznych Polskiego Towarzystwa Psychologicznego; 1999 (in Polish).

10. Kropornicka B, Baczewska B, Stefaniak E, et al. Zachowania prozdrowotne pacjentów z cukrzycą typu 2. Przeds Zarz 2013; XIV(10): 395-408 (in Polish).

11. Kurpas D, Kusz J, Jedynak T, et al. Ocena częstości podejmowania zachowań zdrowotnych w grupie pacjentów chorych przewlekle. Fam Med Prim Care Rev 2012; 14(2): 183-185 (in Polish).

12. Smoleń E, Gazdowicz L, Żyłka-Reut A. Zachowania zdrowotne osób starszych. Pielęg XXI w 2011; 36(3): 5-9 (in Polish).

13. Moczydłowska A, Krajewska-Kułak E, Kózka M, et al. Stopień akceptacji choroby przez pacjentów oddziałów zachowawczych i zabiegowych. Pielęg Chir Angiol 2014; 2: 62-70 (in Polish).

14. Grochans E, Gburek D, Polakiewicz P, et al. Ocena zachowań zdrowotnych pacjentów z uwzględnieniem zmiennych socjodemograficznych. Fam Med Prim Care Rev 2012; 14(2): 148-150 (in Polish).

15. Ślusarska B, Nowicki G. Zachowania zdrowotne w profilaktyce chorób układu krążenia wśród osób pracujących. Probl Hig Epidemiol 2010; 91(1): 34-40 (in Polish).

16. Kurowska K, Sulkowska J. Poczucie koherencji a zachowania zdrowotne wśród pensjonariuszy Domu Pomocy Społecznej (DPS) - badania wstępne. Psychogeriatria Pol 2011; 8(2): 73-80 (in Polish).

17. Szafraniec R, Szczuka E, Pawłowska A. Akceptacja choroby przez pacjentów z reumatoidalnym zapaleniem stawów. Fizjoter Pol 2012; 12(1): 39-48 (in Polish).

18. Olszak C, Nowicka E, Baczewska B, et al. Wpływ wybranych czynników społeczno-demograficznych i medycznych na akceptację choroby w grupie osób z cukrzycą typu 2. Journal of Education, Health and Sport 2016; 6(12): 11-28, doi: http://dx.doi.org/10.5281/zenodo.192107 (in Polish).

19. Araszkiewicz A, Piasecka D, Wierusz-Wysocka B. Ocena wiedzy pacjentów z typem 2 cukrzycy na temat przewlekłych powikłań choroby. Now Lek 2012; 81(2): 158-163 (in Polish).

20. Powers MA, Bardsley J, Cypress M, et al. Diabetes self-management education and support in Type 2 Diabetes: a joint position statement of the American Diabetes Association, the American Association of Diabetes Educators, and the Academy of Nutrition and Dietetics. Clin Diabetes 2016; 34(2): 70-80, doi: 10.2337/diaclin.34.2.70.

Tables: 2

Figures: 0

References: 20

Received: 07.05.2018

Reviewed: 22.05.2018

Accepted: 01.08.2018
Address for correspondence:

Małgorzata Starczewska, DHSc

Zakład Pielęgniarstwa PUM

ul. Żołnierska 48

71-210 Szczecin, Polska

Tel.: +48 91 480-09-10

E-mail:mlary@pum.edu.p 